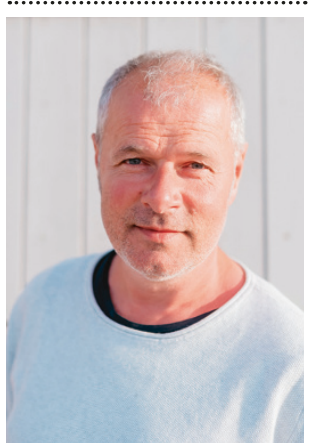

Gerben Bergsma is verpleegkundige, adviseur en trainer. $\mathrm{Hij}$ adviseert teams in vastgelopen zorgsituaties via het Centrum voor Consultatie en Expertise (CCE, kosteloos). Bovendien is hij lid van het Expert Netwerk Verpleegkunde, een initiatief van TVZ en Nursing waarin abonnees kennis delen met elkaar. Zie www.nursing.nl/netwerk.

Mevrouw Warringa ziet en hoort mensen die er niet zijn. Verpleegkundigen in de wijk schrikken als ze plotseling boos uitvalt tegen haar imaginaire belagers. Sommigen worden boos, en dan is er ruzie.

tekst Gerben Bergsma

\title{
Schreeuwen tegen onzichtbare vijanden
}

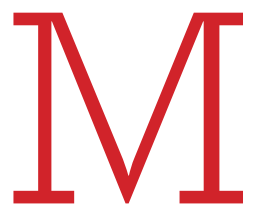
evrouw Warringa (76) woont in het buitengebied in een vervallen dijkhuisje. Het gras groeit in de dakgoten en de kozijnen zijn verrot. Als het waait flakkeren binnen de kaarsen en rammelen de dakpannen. Mevrouw schijnt er geboren te zijn, maar niemand weet dat zeker. Mevrouw laat niets over haar verleden los en soms niemand binnen. $\mathrm{Ze}$ is regelmatig achterdochtig en praat soms tegen denkbeeldige personen.

\section{Niemand is te vertrouwen}

Mevrouw Warringa ontvangt al jaren wijkverpleging: een paar keer per week bij de ADL en voor het uitzetten van haar diabetesmedicatie. Andere medicatie, zoals antipsychotica, weigert ze steevast. Terwijl ze er wel baat bij zou kunnen hebben volgens de psychiater, die ze consequent de deur wijst.

Het pittoreske huisje van mevrouw is vies, zeg maar gerust ontzettend smerig. Het ruikt muf en regelmatig komt er een vleugje kattenpis voorbij. Zelf schijnt ze er geen last van te hebben. Ze scharrelt er tevreden tussen de rommel rond, terwijl haar rode kater langs haar kuiten strijkt. Alleen de verpleegkundigen in de wijk zijn welkom, andere hulpverleners niet, en familie evenmin. Mevrouw houdt de deur stijf dicht. Niemand is te vertrouwen!

De verpleegkundigen vinden het lastig, zeker als mevrouw schreeuwt tegen personen die er niet zijn. Sommigen schrikken zich wezenloos, worden bang en trekken zich terug. Anderen worden boos en corrigeren haar, wat leidt tot ruzie, waardoor mevrouw hen de deur wijst en de zorg achterwege blijft.

\section{TIPS VOOR OIMGAAN MET IMENSEN MET SCHIZOFRENIE}

1 Wees niet te uitgesproken, dat kunnen mensen met schizofrenie als belastend ervaren.

2 Bestrijd waanideeën of hallucinaties niet. Je kunt wel aangeven dat jij die ervaringen niet hebt.

3 Vragenderwijs helpen de gedachte aan de realiteit te toetsen wil wel eens helpen. 'Kan het zijn dat de burgemeester te druk is om specifiek $u$ in de gaten te houden?'

4 Mensen met schizofrenie hebben baat bij een zekere structuur, maar niet bij een dwingende structuur; ritme is belangrijk, maar houd de persoon niet te strak aan (tijds)afspraken vanwege de stress die dat oplevert.

5 Probeer mensen met schizofrenie te helpen stress te beperken. Stress - bijvoorbeeld door te veel activiteiten, zorgen, slaaptekort, et cetera - is een belangrijke trigger voor psychotische symptomen.

6 Help bij het organiseren en plannen van (ogenschijnlijk) eenvoudige activiteiten. Bijvoorbeeld met de dagindeling: eerst afwassen, dan een wandelingetje, dan naar de benzinepomp voor een pakje shag. Mensen met schizofrenie hebben hier moeite mee.

7 Vermijd directieven. Probeer liever rustig te overtuigen.

8 Zoek oplossingen die passen binnen de belevingswereld van de patiënt. Zoals bij mevrouw Warringa het wegjagen van de enge honden of het afplakken van de camera's in het behang. 


\section{Meebewegen}

Janneke, een door de wol geverfde verpleegkundige, heeft een andere strategie. Ze gaat mee in het verhaal, vraagt wat er aan de hand is en geeft mevrouw groot gelijk. Zo schreeuwt mevrouw soms tegen een denkbeeldige persoon dat hij zijn waffel moet houden, want 'hij wil dat ik me van kant maak.' Janneke spreekt er met mevrouw schande van. Dat werkt: het maakt haar rustiger.

Een volgende keer zit mevrouw met grote ogen bij de petroleumkachel, en roept 'Ga weg! Ga weg!' Als ze Janneke ziet, vraagt ze haar alsjeblieft de honden weg te jagen die haar aanvallen. Janneke pakt een vuilniszak, rent door het vieze kamertje, werpt alle zogenaamde viervoeters in de zak en zet die buiten. 'Zo, die zijn weg'. Mevrouw bedankt haar hartelijk en helpt daarna een handje met het uitzetten van de medicatie. De aangeboden oploskoffie in een kopje dat in jaren niet is afgewassen, slaat Janneke beleefd af.

\section{Achterdocht}

Moeilijk is het ook als mevrouw zich achterdochtig toont. Bijvoorbeeld naar de buren, 'die bespioneren mij met onzichtbare cameraatjes in het behang'. Soms is mevrouw overtuigd van een wereldwijd complot tegen haar. Covid-19 is door de burgemeester ontwikkeld om juist bij haar een chip in te kunnen brengen. Janneke probeert mevrouw vragen te stellen om haar te helpen met haar ideeën. 'Zou de burgemeester het daar niet veel te druk voor hebben?'. Zo'n vraag helpt wel eens om mevrouw op andere gedachten te brengen. Maar niet altijd.

\section{Begrip voor de zielkte}

Met het team bespreken we wat wanen precies zijn: irreële gedachten met een bizarre inhoud, zoals de camera's in het behang. Verder zijn er de hallucinaties, de voor mevrouw levensechte waarnemingen die niet op de werkelijkheid berusten. Als zorgverleners weten wat er aan de hand is met een cliënt, neemt de angst vaak af en reageren ze met meer begrip.

Mogelijk lijdt mevrouw aan schizofrenie, een psychotische aandoening die zich in of kort na de adolescentie openbaart en die golfsgewijs optreedt. In periodes dat de hallucinaties en wanen achterwege blijven, hebben patiënten vaak moeite met concentratie, met het organiseren van eenvoudige handelingen, en met initiatief nemen. Mevrouw Warringa hoort stemmen en is achterdochtig. Ook duidt de rommel in en om

\section{Psychotische stoornissen}

Mevrouw Warringa heeft waarschijnlijk schizofrenie. Psychotische episodes horen bij dit ziektebeeld. Ongeveer $8 \%$ van de volwassen bevolking heeft wel eens een psychotische beleving gehad.' Naar schatting zijn 120.000 - 150.000 Nederlanders onder behandeling voor een psychotische stoornis. Die bestaat vaak uit leefvoorschriften en antipsychotica. De nieuwe generatie antipsychotica (bijv. risperidon, quetiapine en clozapine) geeft minder bijwerkingen dan de klassieke antipsychotica (zoals haloperidol, flupentixol en zuclopentixol).

haar huis op moeite met plannen en organiseren.

\section{Bejegening}

Wat betreft de bejegening bespreken we dat het zinvol is om mevrouw met weinig druk (niet te vriendelijk, niet te stellend, niet te vrolijk) te benaderen, omdat mensen met schizofrenie dat als bedreigend en stressvol ervaren.

Ook de interventies 'meebewegen of tegenspreken' komen aan bod. Vaak heeft het geen zin om hallucinaties af te doen als onecht, omdat de patiënt ze als levensecht beleeft. De patiënt voelt zich dan vaak eenzaam in een soms heel bedreigende wereld.

Het werkt beter om oplossingen te helpen bedenken die passen in de beleving van de persoon met de psychose. Soms werkt het echter ook om de patiënt te helpen beseffen dat de gedachte of beleving niet reëel is. Er is dus geen wet van Meden en Perzen. De juiste manier is persoonsen situatiegebonden.

\section{Minder in conflict}

$\mathrm{Na}$ een tijdje is er een tweede teambijeenkomst. De verpleegkundigen hebben geëxperimenteerd met de besproken interventies. Mirjam heeft bijvoorbeeld de enge honden het erf afgejaagd en Bousra heeft mevrouw geadviseerd een onzichtbaar cameraatje af te plakken met schilderstape ('dat beschadigt het behang niet als u het er weer afhaalt').

We stellen samen vast dat mevrouw nog steeds bijzondere gedachten heeft en hallucineert, maar verpleegkundigen raken minder in conflict en mevrouw is ook langzaamaan rustiger en vriendelijker geworden.

\section{Noot}

1 www.ggzstandaarden.nl. c6

Benader

mensen met schizofrenie neutraal; niet te dwingend of te vrolijk 95 